\title{
$\begin{array}{llllllllllllllllllllllll}P & R & Z & E & G & L & A & D & Z & A & C & H & O & D & N & I & O & P & O & M & O & R & S & K\end{array}$ ROCZNIK XXXII (LXI) ROK 2017 ZESZYT 4
}

\author{
AgnieszKa Kolodziej-Durnaś, Arkadiusz KolodZieJ \\ University of Szczecin, Wydział Humanistyczny \\ e-mail:kolodziej.durnas@gmail.com,kolodziej.socjologia@gmail.com
}

\section{The idea of maritime upbringing in Poland - THE TRADITION AND CONTEMPORARY MANIFESTATIONS}

Słowa kluczowe: socjologia morska, wychowanie morskie, socjologia wychowania, edukacja morska, młodzież

Keywords: maritime sociology, maritime upbringing, sociology of education, maritime education, youth

In the first part of the article the authors attempt to reconstruct the idea of maritime upbringing which emerged after Poland regained independence and access to sea in 1918 but was developed after the Second World War when and the country's maritime border was extended to the current length of $440 \mathrm{~km}$ (and the seashore line amounting to $770 \mathrm{~km}$ ). The theory and practice of maritime upbringing was undergoing various ideological developments and modifications during the times of communism and the period of transition. In the second part of the article the authors present the results of their own survey carried out among the teachers of four levels of education (from kindergarten to senior high school) in Westpomeranian region. The empirical material gathered was to specify what maritime upbringing means today and how it is practiced in educational institutions. 


\section{The Idea of maritime upbringing in the Polish maritime sociology}

\section{Communist times}

Many politicians, writers and scholars during communist times popularised the idea that Polish people had for ages been associated both physically (by geographical location) and mentally with the Baltic Sea, i.e. were always under the influence of sea ${ }^{1}$. It was also very much emphasized in the literature of those days that Polish access to the sea was always threatened by German territorial expan$\operatorname{sion}^{2}$. That is why Poles should cultivate their belonging to the sea people in order to strengthen their position in the seaside area. In 1946 State Centre for Maritime Upbringing was established as a body of Ministry of Seafaring. In its statute it is stated that: 'maritime upbringing means shaping a type of citizen, a man of work and dead comprehending maritime reality, having knowledge on labour in seafaring and port and willing to work there because of real and tested love and understanding'. The lessons of maritime upbringing are conducted because of the need to win 'healthy' selected staff to operate in the maritime economy, especially merchant navy and deep-sea fishing ${ }^{3}$.The need of maritime education was during the communist times strengthened by the threads of lowering of attractiveness of work at sea. Many observations shows that work at sea becomes more attractive only during the period of higher unemployment and lack of alternative of work on land. Historically speaking the work on deep-sea vessel was frequently associated with forced labour. The profession of a seafarer despite the fact that it was a typically male occupation through centuries exhibited rather low social status. Therefore in communist Poland a system of material and non-material incentives was developed to motivate young people to choose this tough 'nautical' path of life. Material factors are most of all access to foreign currencies (money of real value) and to goods which could be purchased thanks to them and which were unavailable in Poland. The non-material factors were shaped within the frames of 'maritime upbringing'. The labour at sea required high qualifications from one hand and the renouncement of social contacts and possibility of free organization of one's leisure time ${ }^{4}$. It was predicted that these needs difficult to be met at sea

\footnotetext{
${ }^{1}$ T. Ocioszyński, Rozwój żeglugi i myśli morskiej, Gdynia 1968, p. 261.

${ }^{2}$ Ibidem, p. 266-284.

${ }^{3}$ R. Woźniak, Problemy socjologii wychowania morskiego. Socjologiczne studium wychowania na statku morskim, Szczecin 1987, p. 49.

${ }^{4}$ Milian L., Zawód marynarza floty transportowej, Gdynia 1974, p. 10.
} 
(of social and cultural nature) will be more and more significant and therefore discouraging to start working in maritime industry. That is why the issue of shaping proper motivation encouraging to learn and study maritime professions and to bear the difficulties of labour at sea in the future became more and more important. This tendency (to encourage work at sea) was manifested even earlier - during the interwar period, also within the maritime schools themselves. The students of these schools, provided they had a choice, were often choosing the job on land ${ }^{5}$. Thus they had to be constantly motivated also during the period of study to become a person performing maritime professions.

During communist times the idea of maritime upbringing included processes of upbringing of grown-up seamen and fishermen on boards of deep-sea vessels. The socialist ideology assumed that workers should be observed, shaped in order to control them and not to let them develop doubts about the 'great advantages' of living in the communist system. Also the maritime professions workers were encouraged to conduct educational activities because the authorities wanted to have this message passed to younger generations ${ }^{6}$.

Adam Sosnowski and Jerzy Walkowiak understand maritime education as the formation of role complex preparing to work at sea 7 . Such education may take place in secondary vocational schools and higher maritime academies (one of the characteristic parts of such education is temporary isolation from the school surrounding ${ }^{8}$. As the authors made their research during communist times they suggest that within the maritime education there is an ideological component and they think maritime professionals should be especially ideologically conscious and active in social and political life. The authors also complain that maritime upbringing and education at secondary vocational schools and in maritime academies is directed almost totally at shaping disciplined individuals and not at shaping creative and innovative individuals ${ }^{10}$. This may stem from the fact that work at sea poses from the point of view of central authorities also certain threats

\footnotetext{
${ }^{5}$ Ibidem, p. 60.

${ }^{6}$ Compare e.g. T. Olchowy, Działalność kulturalno-oświatowa załóg statków morskich, Szczecin 1967.

${ }^{7}$ A. Sosnowski, J. Walkowiak, Edukacja w szkołach morskich. Szkic socjologiczny, Szczecin 1983, p. 6-7.

${ }^{8}$ Ibidem, p. 16.

${ }^{9}$ Ibidem, p. 31.

${ }^{10}$ Ibidem, p. 83.
} 
- e.g. the opportunity to seafarers' escapes from the vessel staying in a foreign port or simply the access to the information about the quality of life in the West.

Within the field of maritime sociology major authors concentrated on the life of fishers and seafarers in labour milieu of a deep-sea vessels. In 1987 Robert Woźniak in his book on the maritime upbringing writes mainly about upbringing on board, however he also states that 'sociology of maritime upbringing is a scientific theory explaining the entirety of upbringing processes taking place in the micro-, meso- and macro area of maritime community ${ }^{11}$. In his later work he enumerates that main areas of maritime upbringing include maritime ideological and moral upbringing, mind-developing upbringing, aesthetical upbringing, physical upbringing, pacifistic upbringing ${ }^{12}$.

\section{Times of Transition}

After the collapse of communism in the Soviet bloc countries the idea of 'maritime upbringing' loses its socialist ideology connotation but is still held dear in some circles of Polish elites.

According to Gronowski 'maritime consciousness' appears in countries with access to sea and it is shaped by certain states to the extent of economic, cultural, educational and even defensive benefits it has because of such geographical location $^{13}$. These processes reflect in the maritime policy of the state.

One may also point to the fact that this special kind of geographical attachment should have a national level of collective unity. Almost after a decade after the start of democratic transformation Piotr Zieliński says ${ }^{14}$ that 'maritime consciousness of the nation' should be built from the very beginning and that the situation in serious and dangerous as the state and nation gave up thinking in maritime terms. The media have special role to play to revive the maritime national feelings.

\footnotetext{
${ }^{11}$ R. Woźniak, Problemy socjologii..., p. 43.

${ }^{12}$ Ibidem, pp. 11-16.

${ }^{13}$ F. Gronowski, Morska racja stanu, in: Morze elementem polskiej racji stanu. Konferencja naukowa, ed. A. Bałaban et al., Szczecin 1999, p. 8.

${ }^{14}$ P. Zieliński, Rola mediów w ksztaltowaniu morskiej świadomości narodu, in: XIV Sejmik Morski. Edukacja morska w Polsce, Szczecin 1998, s. 143.
} 
The text by entitled 'Where is our vision of maritime Poland"15 sounds dramatic. The author says the maritime policy was the cornerstone of the Second Republic of Poland (Polish state after the regaining of independence in 1918) and now it vanished. The author recalls e.g. the efforts to build the identity of Polish Szczecin.

Location at sea is by many treated as a great chance for socio-economic development of the country. Elżbieta Marszałek says that Poland is a maritime state but still cannot make full benefit of this geographical location ${ }^{16}$ (this conviction may become even more persuasive after the collapse of fishery and shipbuilding sectors especially as some people associate it with Poland's access to the EU). Marszałek recalls that recovering independence in 1918 and the access to sea celebrated by the ceremony of marriage with the sea in 1920 triggered the patriotic spurt. The author proves the idea of maritime education and upbringing in primary and secondary education was important for the Polish authorities. The Ministry of Education encouraged the activity of Maritime League (association with its centres or circles at schools responsible for maritime education) and the year of 1986 was announced „Maritime Year in Education”"17. Maritime education is important to win the support of the whole society to undertake major economic investments in the maritime sector $^{18}$, so the final goal is to have a strong state and economy based on maritime industry (among the children and youth today educated in maritime organizations there are future members of Polish central and local authorities).

The idea of maritime upbringing may be included in the wider notion of 'maritime thought' comprises economic, political, social aspects of semantic field of this notion, but also aspects of education and upbringing (also associated with Christian social thought - e.g. Maritime Thought Centre at the Catholic Association 'Civitas Christiana' in Szczecin, compare XIV Sejmik Morski 1998).

\section{Institutions and goals of maritime upbringing}

Związek Harcerstwa Polskiego (Polish Scouts Association) and its Centre of Maritime Upbringing used to organize voyages by Zawisza Czarny - the biggest scouts' sailing boat in the world. During the cruise young people have opportunity

\footnotetext{
15 J. Pachlowski, Gdzie jest nasza wizja Polski morskiej, in: XIV Sejmik Morski..., pp. 177-180.

${ }^{16}$ E. Marszałek, Edukacja morska dzieci i młodzieży jako ważny element wychowania dla przyszłości, in: XIV Sejmik Morski..., p. 101.

${ }^{17}$ Ibidem, p. 103.

${ }^{18}$ Com. ibidem, p. 105.
} 
to shape qualities needed to function in contemporary world - extreme emotions, great chance for co-operation, team-work, challenging tasks on board. All this results in great educational goals one may achieve in upbringing young people (mainly teenagers) ${ }^{19}$. Such camps on board were organized also on other vessels: e.g. 'Dar Pomorza' or 'Kościuszko'. This seems to be the most spectacular way of conducting maritime upbringing (but there were many other ones - see below). Such a voyage was also the most attractive form which supported and facilitated other forms of maritime upbringing constituting the reward for the most engaged young people.

In many schools in the region of Pomerania and Western Pomerania an organization called Maritime League used to operate. Various programmes often supported by community authorities were pursued in primary and secondary schools (e.g. in Gryfice). Also the contest called 'Nautological Olympic Games' was conducted in many schools.

Eugenia Mańkowska proves that maritime upbringing may be treated as one of the therapeutic forms ${ }^{20}$. Centres of Maritime Leagues (but also National Defence League) not only provided places with maritime decoration for young children to play games and study together to contests, etc., but also took part in preparing programmes of social therapy, resocialization, various workshops.

To conclude the understanding of the idea of maritime upbringing one may say that it was to perform at least a few functions: ideological (justification of Polish communist authority over regained seaside territories), educational (knowledge on the seaside region), economic (encouraging young people to plan their career in maritime professions), therapeutic and general upbringing (socialization) one - preparation to live in a society.

\section{Some remarks on understanding of the idea of maritime upbringing from foreign authors}

Butzow ${ }^{21}$ worked out a schedule to teach children at primary and secondary school about maritime heritage. The course included information on maritime history,

${ }^{19}$ W. Mieczkowski, Działalność centrum wychowania morskiego ZHP, in: XIV Sejmik Morski..., pp. 119-121.

${ }^{20}$ E. Mańkowska, Wychowanie morskie jako jedna z form terapii, in: XIV Sejmik Morski..., pp. 195-197.

${ }^{21}$ J.W. Butzow, What is Our Maritime Heritage? A Marine Education Infusion Unit on Ships and Sailing, Orono 1980. 
basics of sailing, data on ships and shipping, creating models of boats, singing sea chanties, playing board games, reading prose and poetry.

Maritime upbringing and early maritime education may be the means to attract young people to maritime professions and this would be beneficial for economy as in this branch there is very low unemployment rate if any ${ }^{22}$.

Lileikis discusses the idea of maritime upbringing from the point of view of biology, psychology and spirituality. The author elaborates on the axiological relationship between personality and sea, mentions that already Freud was writing about that and e.g. Frankl was one of those scholars who noticed that staying close to the sea means 'recognition of relaxation, aesthetic environment, transcendence above the trivial surrounding and self-development ${ }^{23}$. A person who is staying at sea can experience a time of self-reflection, and transcend the problems of every-day life, get a distance to them also thanks to the sounds and colours of sea and its surrounding. Thanks to the relation with sea a man can overcome the anxiety of existence.

\section{Current understanding and practicing of maritime upbringing - research project}

In the matrix concept of maritime sociology Wioleta Bryniewicz ${ }^{24}$ there is no such discipline mentioned as sociology of education or sociology of upbringing but there are: sociology of sport and sociology of culture the findings of which may be feeding the idea of maritime upbringing. As the concept of maritime sociology itself has been since the beginning of transformation less present in the public opinion and among stakeholders of maritime industry companies and institutions also the idea of maritime upbringing may have been forgotten. The authors of this article undertook to prepare and conduct a research project aimed at the checking how the concept of maritime upbringing is currently understood.

The research tool was based on the questionnaire and the sample was composed of 50 schools and kindergartens divided into 4 quotas dedicated to different level of education, each composed of 25 persons. The respondents were teachers representing these educational institutions describing (as experts) activities of

\footnotetext{
22 J. Berzins, I. Barbare, Development of Maritime Human Resources and Education. Career Education in Latvian Maritime Academy, "European Integration Studies" 2013, no. 7, pp. $14-17$.

${ }^{23}$ S. Freud, Das Unbehagen in der Kultur, Wien 1930; V.E. Frank1, Psychotherapy and Existentialism, New York 1967; S. Lileikis, Jurines Edukacijos Psichofelicitologinis Matmuo (Psychofelicitological Dimensions of Maritime Upbringing), “TILTAI” 2009, 4, p. 136.

${ }^{24}$ W. Bryniewicz, Geneza i dzieje socjologii morskiej, Szczecin 2004, pp. 24-38.
} 
their schools and expressing their opinions in this regard. The authors received 46 filled in questionnaires. The largest number of collected questionnaires was collected from the teachers of pre-school level (kindergarten teachers - 20), the least numerous - from the primary school teachers -5 . Teachers from junior high school sent back 11 questionnaires and these of senior high schools -7 . Three questionnaires came from education institutions were teachers work in both junior high school and senior high school. The age distribution of the sample population may be analysed as follows. Respondents were divided into five age categories (five decades starting with 20-29 and 60-69 to end with). The number of teachers responding in these age groups was $2,11,16,13,4$ respectively. Thus the most numerous group of respondents were people at the age of 40-49 which means they remember communist times although some of them grew up during the transformation period (so they may also remember the idea of maritime upbringing promoted by maritime institutions active before the collapse of the old regime). The second largest age category is even older. The least numerous group is young teachers who do not remember communist times.

The research project was aimed at exploration of opinions among the teachers of Westernpomeranian schools and kindergartens and the overwhelming majority of respondents confirmed that they introduce the elements of maritime upbringing into their classes:

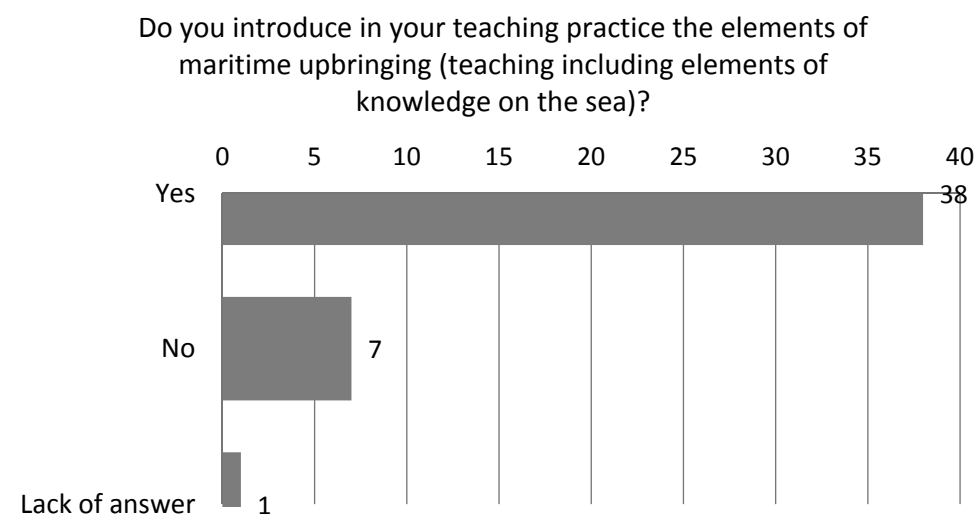

Chart 1. Elements of maritime upbringing in teaching practice Source: authors' own research. 
The elements of teaching which are usually (according to the previous literature on maritime sociology) treated as associated of maritime upbringing are of course linked to the topic of sea and have the form of games and fun, poems and songs of maritime themes, talks about maritime issues, contests checking knowledge on the maritime issues, reading children books on maritime adventures, etc. When respondents of this project were asked what other forms of teaching practice concerning maritime upbringing they conduct some of them agreed to give some examples. The answers were classified into the following categories: cultural elements (literature, film, holidays), conceptual elements (constructions, tasks and problems to solve), physical activity and tourism elements (trips, sailing, sightseeing), social activities (meeting people performing maritime professions). In the first category there are 4 utterances out of total number of 17, in the second -3 , the third is the most numerous with 7 utterances and the last one with 3 kinds of activities (see Chart 2). Some of the examples given by the teachers were very interesting, eg. teaching maritime dances, instructing how to construct a boat, taking part in the celebration of launching a vessel, the festival of 'accolade for a seaman'.

\section{What activities do you introduce within the frames of maritime upbringing? Other ones - what kind of?}

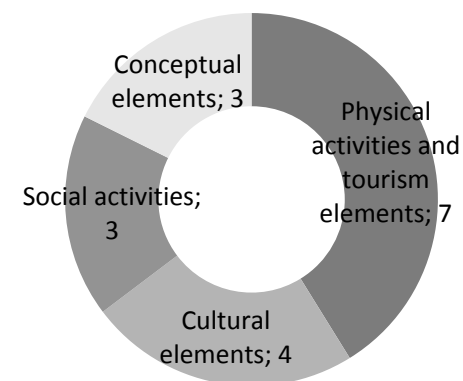

Chart 2. Forms of maritime upbringing introduced in teachers' practice

Source: authors' own research.

The other issue included in the objectives of the research study was to find out what is in the teachers' opinion the main goal of practicing maritime upbringing nowadays. Teachers gave many different answers. They were categorised in 
a few groups: transmitting knowledge, creating local identity, inducing ecological sensitivity, preparing to work in maritime professions, instructing water sports and seaside tourism, developing aesthetic sensitivity, emphasizing the economic significance of maritime industry, strengthening patriotism (see Table 1).

Table 1. Main goals of practicing maritime upbringing according to teachers

\begin{tabular}{|l|c|}
\hline \multicolumn{1}{|c|}{ Categories } & Number of utterances \\
\hline $\begin{array}{l}\text { To transmit knowledge: } \\
\text { on the region }-6, \\
\text { on maritime professions }-4, \\
\text { on maritime infrastructure and maritime means of transport }-5, \\
\text { on maritime culture - 4. }\end{array}$ & 19 \\
\hline To create local identity & 10 \\
\hline To induce ecological sensitivity & 6 \\
\hline To emphasize the significance of maritime industry & 6 \\
\hline To promote and instruct water sports and tourism & 6 \\
\hline To develop aesthetic sensitivity & 3 \\
\hline To strengthen patriotism & 2 \\
\hline To prepare to work in maritime professions & 2 \\
\hline Other & 5 \\
\hline Total & 59 \\
\hline
\end{tabular}

Question of multiple choice

Source: authors' own research.

Among the answers given there were such as: promotion of the region, teaching pupils about the maritime means of transport, specificity of maritime professions, ensure safety during summer holidays at the seaside, making young people sensitive to maritime environment, shaping the ability to notice maritime beauty, passing knowledge about maritime fauna and flora, inducing the attachment to the region, making people conscious what kind of benefits may maritime location bring, creating maritime identity among children, popularising sailing, showing the unique character of the region, pointing to ecological problems, etc. The utterances aimed at showing the main goal of maritime upbringing may be divided into the ones linked with autotelic and instrumental values. These associated with aspects of living by the sea facilitating striving for beauty, harmony or good are autotelic ones. The instrumental ones are these pointing to economic aspects or otherwise practical aspects.

Respondents were also asked to give the goals of maritime upbringing during the communist times. The answers were again categorised in the same captions. 
According to their opinions the most important goal was to prepare young people to work in maritime professions (20\% of responses), secondly - to emphasize the significance of maritime industry $(16 \%)$ and thirdly to strengthen patriotism $(12 \%)$.

Table 2. Main goals of practicing maritime upbringing during communist times according to teachers

\begin{tabular}{|l|c|}
\hline \multicolumn{1}{|c|}{ Categories } & Number of utterances \\
\hline To transmit knowledge on sea & 3 \\
\hline To create local identity & 3 \\
\hline To induce ecological sensitivity & 0 \\
\hline To emphasize the significance of maritime industry & 0 \\
\hline To promote and instruct water sports and tourism & 0 \\
\hline To develop aesthetic sensitivity & 6 \\
\hline To strengthen patriotism & 10 \\
\hline To prepare to work in maritime professions & 3 \\
\hline I do not know & 17 \\
\hline Lack of answer & 50 \\
\hline Total & \\
\hline
\end{tabular}

Source: authors' own research.

Although the sample of respondents is not large one may try to compare these two sets of answers. According to the teachers asked the main goal of maritime industry currently is to transmit knowledge on sea and create local activity and previously it was rather preparing young people to work in maritime professions and emphasize the significance of maritime industry. This may be referred to as a shift from practical, material aspects (heavy industry) to light aspects (soft power, postmaterial values - image, consciousness, regionalism).

As judging from the attributed goals maritime upbringing represents a great mission to be fulfilled. The question is however whether it should be practised all over Poland or only in the seaside area (Pomeranian provinces). Teachers who participated in the survey gave their opinion about this issue (see Table 5). The majority of respondents $(87 \%)$ think the elements constituting maritime upbringing should be taught all over the country and not only in the seaside regions. This may mean that even its "local" goals as creating regional identity finally contribute to the ideal of citizen of the country - the citizen, who is during their young years being equipped with values which take their beginnings in the sea as a natural environment but in the process of transforming it into social space was enriched with the values 
one think any human being should have and may be proud of. Only 13 percent of respondents say maritime upbringing should be practised in the seaside area linking the values it should carry along as the ones needed by the inhabitants of Pomerania regions, and probably possible future maritime professionals.

Table 3. Where maritime upbringing should be practised?

\begin{tabular}{|l|c|c|}
\hline \multirow{2}{*}{\multicolumn{1}{c|}{ Answers }} & $\begin{array}{c}\text { Q7: Should maritime upbringing be practised only in the seaside } \\
\text { area (Pomerania region) or all over the country? }\end{array}$ \\
\cline { 2 - 3 } & Number of utterances & Percent \\
\hline Only in the seaside area & 6 & 13 \\
\hline All over the country & 40 & 87 \\
\hline
\end{tabular}

Source: authors' own research.

The authors of the research project were also interested what respondents think about the future of Westpomeranian region and its association with seaside location. As the teachers are part of the elites which create the conditions for next generations one may say that at least in this layer of the society the future of the region may be quite bright. Over 60 percent of teachers asked whether the sea will have more and more significance for the development of our region answered that its significance will be rising (see Chart 3). Only less than 7 percent said that the significance will be falling.

Will sea (seaside location) have more and more significance for the development of our region?

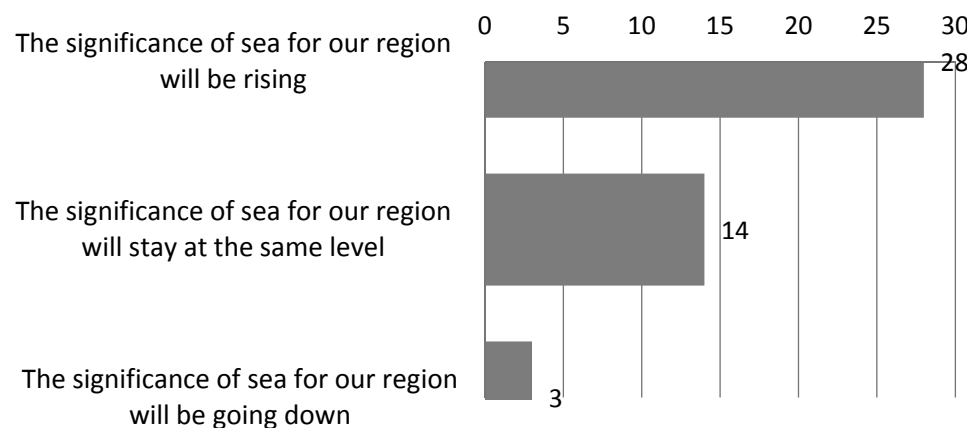

Chart 3. Significance of the seaside location for the development of the Westpomeranian region

Source: authors' own research. 


\section{Conclusions: Transformations of 'maritime upbringing' idea and practice}

The idea of maritime upbringing has been mainly developed in communist Poland and analysed by maritime sociology. At that time it had to perform mainly political (ideological) functions associated with the need of incorporating newly regained seaside territories to Poland and integrating it culturally with the rest of the country as well as showing Poles what advantages will new location have.

After the red regime collapse in 1989 the transformation of economic system and introduction of free-market rules resulted in many maritime companies closed down. Maritime upbringing now is more directed towards building regional identity, tourism, and sustainable development although the economic dimension and the "advertising" maritime professions may be reborn.

The main directions of the change within the phenomenon of maritime upbringing may be summed up as follows:

1. Shift from results of political importance to economic importance. Although this may be only partially true as during the communist times the economic factor has been also significant. People promoting maritime upbringing were afraid of the reduction of maritime professions attractiveness and the plans of authorities to develop deep-sea transport fleet ${ }^{25}$. Maritime upbringing may include pre-vocational training which is very valuable for young people entering the labour market the more so that vocational training in shipping industry is reduced due to costs, employer's fear of losing better-skilled employees in favour of competition, etc. ${ }^{26}$.

2. Shift from central authorities to regional authorities. Regional aspect of maritime upbringing is emphasized. The need to build regional identification of inhabitants correlates with the demographic crisis and negative balance of migration (more people emigrate from the country than immigrate to it). Maritime upbringing may constitute a factor linking an individual with the seaside region and contributing to the process of decision making about the staying in one's local homeland

3. Shift from ideology to individual's (physical, psychological and social) well-being. The change from the demand for employees (during the communist times the anxiety of how to ensure a proper number of willing to

\footnotetext{
${ }^{25}$ L. Milian, Zawód marynarza..., p. 10.

${ }^{26}$ Com. H. Sampson, L. Tang, Strange things happen at sea: training and new technology in a multi-billion global industry, "Journal of Education and Work" 2016, vol. 29 (no. 8), pp. 980-994.
} 
work) to the reduction of unemployment (seaman may be employed by a foreign ship owner but live in Poland - reduction of unemployment rate by pushing him to the global market).

\section{Bibliography}

Berzins J., Barbare I., Development of Maritime Human Resources and Education. Career Education in Latvian Maritime Academy, "European Integration Studies" 2013, no. 7, pp. 14-17.

Bryniewicz W., Geneza i dzieje socjologii morskiej, Szczecin 2004.

Butzow J.W., What is Our Maritime Heritage? A Marine Education Infusion Unit on Ships and Sailing, Orono 1980.

Frankl V.E., Psychotherapy and Existentialism, New York 1967.

Freud S., Das Unbehagen in der Kultur, Wien 1930.

Gronowski F., Morska racja stanu, in: Morze elementem polskiej racji stanu. Konferencja naukowa, ed. A. Bałaban et al., Szczecin 1999.

Lileikis S., Jurines Edukacijos Psichofelicitologinis Matmuo (Psychofelicitological Dimensions of Maritime Upbringing), "TILTAI” 2009, 4, pp. 125-139.

Mańkowska E., Wychowanie morskie jako jedna z form terapii, in: XIV Sejmik Morski. Edukacja morska w Polsce, Szczecin 1998, pp. 195-197.

Marszałek E., Edukacja morska dzieci i młodzieży jako ważny element wychowania dla przyszłości, in: XIV Sejmik Morski. Edukacja morska w Polsce, Szczecin 1998, pp. $101-110$.

Mieczkowski W., Działalność centrum wychowania morskiego ZHP, w: XIV Sejmik Morski. Edukacja morska w Polsce, Szczecin 1998, pp. 119-121.

Milian L., Zawód marynarza floty transportowej, Gdynia 1974.

Ocioszyński T., Rozwój żeglugi i myśli morskiej, Gdynia 1968.

Olchowy T., Działalność kulturalno-oświatowa załóg statków morskich, Szczecin 1967.

Pachlowski J., Gdzie jest nasza wizja Polski morskiej, in: XIV Sejmik Morski. Edukacja morska w Polsce, Szczecin 1998, pp. 177-180.

Sampson H., Tang L., Strange things happen at sea: training and new technology in a multi-billion global industry, "Journal of Education and Work" 2016, vol. 29 (no. 8), pp. 980-994.

Sosnowski A., Walkowiak J., Edukacja w szkołach morskich. Szkic socjologiczny, Szczecin 1983.

Woźniak R., Problemy socjologii wychowania morskiego. Socjologiczne studium wychowania na statku morskim, Szczecin 1987, p. 49.

Zieliński P., Rola mediów w ksztattowaniu morskiej świadomości narodu, in: XIV Sejmik Morski. Edukacja morska w Polsce, Szczecin 1998, pp. 143-152. 


\title{
Abstract
}

Maritime upbringing is the category used by maritime sociologists at least for half a century. At first the authors take an attempt to reconstruct the idea of maritime upbringing which emerged after the Second World War. Next they refer to the idea of maritime upbringing and education discussed during the transformation and then to the current understanding and ways of implementing it in Poland and abroad. The authors conducted an introductory research project among Polish Westpomeranian teachers to find out about the scope, significance and forms of maritime upbringing realized these days in Polish seaside areas. They elaborate on the results concentrating on forms and goals of maritime upbringing as well as the prospects for the seaside region development.

\section{IDEA WYChowania MoRskiego w Polsce - TRADYCJA I WSPÓECZESNE PRZEJAWY}

\begin{abstract}
Abstrakt
Wychowanie morskie jest kategorią używaną przez socjologów morskich przynajmniej od półwiecza. Na wstępie autorzy podejmują próbę zrekonstruowania idei wychowania morskiego, która pojawiła się po II wojnie światowej. Następnie odnoszą się do wychowania morskiego i edukacji morskiej jako zagadnień podejmowanych w czasie transformacji, jak również do obecnego rozumienia i dróg realizowania wychowania morskiego w Polsce i poza jej granicami. Autorzy przeprowadzili wstępne badania wśród zachodniopomorskich nauczycieli, by dowiedzieć się, jaki jest: zakres, znaczenie i formy wychowania morskiego praktykowanego współcześnie na polskim wybrzeżu. Opisują oni rezultaty, koncentrując się na formach i celach wychowania morskiego, a także perspektywach rozwoju regionu.
\end{abstract}

